\title{
DE NIEUWE AFDEELING VAN HET MILITAIR HOSPITAAL TE PARAMARIBO VOOR BESMETTELIJKE ZIEKTEN
}

(Met 15 afbeeldingen)

$$
\text { DOOR }
$$

P. COOL

Off. v. Gez. $1^{\text {e }}$ kl. Chef Mil. Geneesk. Dienst in Suriname

De 11e Juni 1924 zal een belangrijke datum blijven in de geschiedenis van het Militair Hospitaal te Paramaribo, de dag der officieele opening van de Nieuwe Besmettelijke Afdeeling door den waarnemenden Gouverneur Mr. L. J. Rietberg. Van dit Hospitaal alleen of wellicht ook voor de stad Paramaribo, voor geheel Suriname? Slechts hij, die de toestanden in deze West-Indische kolonie niet kent, zal dit laatste ontkennend kunnen beantwoorden. Te veel heeft de Surinamer in zijn onfortuinlijke vaderland tot verval zien komen, ook van datgene wat eertijds hecht en sterk leek, te veel vóór- in tegenspoed zien veranderen, dan dat hij niet met geheel zijn hart zou hangen aan eene instelling, dîe, ondanks de chronische geldzorgen der kolonie, zich niet alleen heeft gehandhaafd maar er in is geslaagd den naam te verkrijgen en te behouden van eene der beste inrichtingen op dit gebied van geheel WestIndië, die vele vreemdelingen uit naburige koloniën tot zich blijft trekken. Aan welke gelukkige omstandigheid is het te danken, dat dit hospitaal, in 1760 opgericht, niet werd medegesleept in den algemeenen achteruitgang en teruggebracht tot een bescheiden ziekeninrichting voor het steeds kleiner wordende garnizoen? Twee oorzaken werkten hiertoe mede: Ten eerste het feit, dat in 1821 het Burgergasthuis verbrandde en van af dat oogenblik het Militaire Hospitaal de eenige en centrale ziekeninrichting 
van Suriname werd; ten tweede de omstandigheid, dat de onkosten van dit hospitaal - met die van de troepenmacht - vroeger geheel en den laatsten tijd nog voor een zeer belangrijk deel worden gedragen door Nederland zelf. In beheer en organisatie bleef het hospitaal aldus militair, en in geldelijk opzicht onafhankelijk van de meerdere of mindere welvaart der kolonie. Toch is het er al die jaren niet minder eene inrichting juist vóór de kolonie, om geweest, niet 't minst doordat er een instituut binnen zijne muren werd gevestigd, op welk ieder Surinamer zoo innig trotsch is. nl. de Geneeskundige School. Oorspronkelijk bedoeld als opleidingsschool voor inheemsche geneesheeren, weinig kostbare hulpkrachten op medisch gebied voor de arme kolonie, ontwikkelde deze school zich tot een niet onbelangrijk instituut van voorbereidend hooger onderwijs, dat den Surinaamschen jongelui in dit voorloopig aan toekomst arme land gelegenheid gaf op Nederlandsch gebied, hetzij in 't Moederland, hetzij in 't groote zustergebied in Azië, een eervolle en behoorlijk bezoldigde sositio to visoverer. II imiruere maar niet onbelängrijke mate heeft ook de in de laatste jaren in het Militair Hospitaal bestaande en in Nederland erkende gelegenheid tot opleiding voor gediplomeerd verpleegster er toe medegewerkt deSurinaamsche meisjes onafhankelijk te maken van de ook op dit gebied geringe vraag naar arbeidskrachten in haar eigen land. Dank zij dezen in 't Militair Hospitaal gevestigden driejarigen leergang vonden velen harer eene behoorlijk bezoldigde betrekking in Nederland of Oost-Indië.

Is het derhalve wonder, dat het Militair Hospitaal met zijn 400 zieken als goed uitgeruste ziekeninrichting, als gelegenheid tot opleiding van geneeskundigen en verplegenden èn als gelegenheid tot werkverschaffing den Surinamer na aan 't hart ligt? En dat hij derhalve voor deze instelling, althans wat den bouw eener nieuwe afdeeling betreft, uit zijn niet ruim voorziene beurs, gelden heeft beschikbaar gesteld, gelden die voor andere doeleinden zoo moeilijk zijn los te krijgen maar van welke hij in dit geval geen oogenblik heeft getwijfeld of zij wel goed en nuttig zouden worden besteed. 
Het was den 21 en April 1920 dat de wd. Gouverneur Mr. Rietberg in eene nota aan de Koloniale Staten de noodzakelijkheid bepleitte voor den bouw eener geheel nieuwe besmettelijke afdeeling van 't Militair Hospitaal. De toestand was inderdaad onhoudbaar geworden en geen bestuur kon de verantwoordelijkheid blijven dragen voor het feit, dat eene infectie-afdeeling geheel zonder eenige afscheiding naast het hoofdgebouw was gelegen, ja dat de voor infectie zoo vatbare kinderen van $1-4$ jaren naast de volwassenen met interne en chirurgische aandoeningen onder de zalen met typhus en dysenterie werden verpleegd, dat derhalve besmette en niet besmette zieken in één barak waren gelegerd. Natuurlijkerwijze was er groote kans dat men in het Militair Hospitaal met typhus werd besmet, hetgeen dan ook inderdaad is voorgekomen. Immers de vloeren dezer uit den tijd van den aanleg van den spoorweg dagteekenende en van dezen overgenomen barakken bestonden en bestaan evenals alle vloeren, ook in 't hoofdgebouw, uit ongeploegde niet aansluitende planken, die door het voortdurende noodzakelijke schrobben en boenen spoedig in zeer slechten toestand komen te verkeeren en dan rijkelijk alle overtollige vocht op de hoofden der in de ,catacomben" vertoevende lijders doen nederkomen. Ik spreek hier met opzet van vertoeven. Van verpleegd worden was hier nimmer sprake, althans niet in modernen zin. Kribben, muskietengordijnen en.... licht ontbraken in deze voor-historische ziekenzalen geheel.

Deze ook officieus catacomben geheeten verblijven leverden eerder gevaar op voor de lijders dan kans op genezing.

Dat zich bovendien onder het gebouw, bestemd voor afzonderlijke verpleging van zware typhus-, dysenterie-, tuberculose-en meningitis-lijders een timmermanswerkplaats bevond, zal in verband met 't bovenstaande niemand verwonderen. Dat het Departement van Openbare Werken deze werkplaats niet kon doen verplaatsen zonder tevens alle reparatiewerkzaamheden aan het Militair Hospitaal te beëindigen is voor een nieuweling in de kolonie moeilijk te begrijpen en bleef zeer te betreuren. Het maakte den toestand voor zware zieken echter volkomen onhoudbaar. 
Alles bijeengenomen meen ik het voor den lezer begrijpelijk te hebben gemaakt, niet alleen dat de nieuwe afdeeling voor besmettelijke ziekten in een lang gevoelde behoefte voorziet, maar dat wij allen reikhalzend naar de voltooiïng hebben uitgezien.

Eerst nu is het niet alleen mogelijk de lijders aan de bekende besmettelijke ziekten uit de oude barakken weg te nemen, maar ook is er nu gelegenheid de in 't hoofdgebouw verpleegd wordende en steeds in aantal toenemende lijders aan longtuberculose naar de nieuwe afdeeling over te brengen, waardoor in dit hoofdgebouw zooveel ruimte is opengekomen, dat eindelijk de catacomben-lijders naar dit hoofdgebouw kunnen verhuizen en deze vochtige donkere verblijven voor goed kunnen worden gesloten als verblijfplaatsen voor zieken. Verbeterd en geverfd zijn deze als schaftlokaal voor personeel en als magazijn uitstekend te gebruiken.

$\mathrm{Na}$ den officieelen openingsdatum der nieuwe besmettelijke afdeeling 11 Juni 1924 is het verdwijnen van den lảatsten catacomben-patiënt op 7 Juli 1924 een dag van bijna even groote beteekenis.

Het terrein over de Sommelsdijksche kreek, in 1914 aangekocht ter eventueele uitbreiding van het Militair Hospitaal werd gedurende de eerste jaren ongebruikt gelaten, hoofdzakelijk door gebrek aan geld. Gedurende den wereldoorlog. toen alle levensbehoeften in prijs stegen, werden op het zeer vruchtbare stuk oude plantage-grond de voor de hospitaal-keuken meest noodige groenten in eigen beheer gekweekt. De eigenlijke bestemming als bouwgrond volgde pas in 't voorjaar van 1921, toen volgens de plannen van den ingenieur Kempees en den dirigeerenden officier van gezondheid 2e klasse Jans begonnen werd met het grondwerk voor den bouw van een hoofdgebouw en zes afzonderlijke paviljoens, voor mannelijke en vrouwelijke verpleegden ieder drie. Dit grondwerk vergde op het 1 Hectare groote terrein in de zware klei veel geld en arbeid. Was de oorspronkelijke bedoeling alle gebouwen op neuten te zetten, spoedig moest men hiervan afzien door de zeer aanzienlijke daarmede gepaard gaande verhooging 
der bouwkosten. Men hield echter vast aan den bouw in steen, in dit geval baksteen. Het eerst gebouwde Militair Hospitaal - nu 't voorgebouw aan de Gravenstraat en dagteekenend uit 1758 - zoowel als het tegenwoordige hoofdgebouw, dat van 1859 dateert, hadden voldoende bewezen dat - de vraag welk bouwmateriaal voor woonhuizen 't meest geschikt is daargelaten - het gebruik van hout voor ziekenhuisbouw ten zeerste is af te raden, terwijl verdiepingbouw eveneens geheel verworpen moet worden. Niet alleen uit een hygiënisch maar ook uit een zuinigheids oogpunt.

Is het in een tropisch land in een steenen gebouw voor iederen hospitaal-chef al een dagelijksche puzzle hoe geregeld bedden en fournituren vrij van ongedierte te houden, daar waar immers op de bezoekuren steeds nieuwe voorraad wordt medegebracht, in een houten ziekenhuis is het volslagen onmogelijk de wandluizen te doen verdwijnen. Wanden en zoldering leveren, vooral in een oud gebouw zooveel schuilplaatsen, dat desinfectie practisch ondoenlijk is. Grondige dagelijksche reiniging der bovenvloeren levert groot ongemak op voor de lijders der beneden zalen en heeft tengevolge dat het hout spoedig verteert, terwijl houtluizen het sloopingswerk voltooien. Een groot houten hospitaal als het tegenwoordige vergt dan ook zooveel geld aan jaarlijksch onderhoud, dat uit de sommen gedurende de laatste eeuw aan onderhoud besteed het hospitaal reeds eenige malen nieuw opgetrokken had kunnen worden. Alleen in de jaren 1907- \pm 1915 werd aan gewoon en buitengewoon onderhoud een som verwerkt van $f$ 120.000.- terwijl toch feitelijk alleen 't allernoodzakelijkste wordt verricht en aan buiten-verf 15 jaren lang niet is gedacht. Het is zooals de vorige Directeur van Openbare Werken zich uitliet beter nergens aan te beginnen, dan ziet men tenminste niet hoeveel en hoever al 't houtwerk is verteerd, en.... behoorlijke herstellingen eischen en eischten veel meer geld dan op de begrooting uitgetrokken kan worden.

$\mathrm{Al}$ deze misère is bij de nieuwe gebouwen voor de toekomst vermeden. Moge men dan al in Suriname, waar 
men niet gewend is met groote getallen om te gaan en vooral in 't begin liever alles op een koopje doet, moge men hier geschrokken zijn van de bouwkosten der nieuwe „barak" ad $f$ 190.000.- , wanneer men de nieuwe besmettelijke afdeeling, waar, zooals gezegd, ook volgens de hier geldende wetgeving ook tuberculose-lijders worden verpleegd, nader beschouwt en 't oog gericht houdt op de toekomst, dan is de bouw uit een zuinigheidsoogpunt zelfs aanbevelenswaardig geweest en naar wij hopen een voorbeeld voor later.

De gebouwen werden opgeleverd 1 April 1924. Alle voorbereidende werkzaamheden inbegrepen heeft de voltooiïng dus ongeveer 3 jaar geduurd. een termijn die niet bijzonder lang is als men weet, dat 't personeel, op den opzichter na, geheel ongeschoold bleek en aan dat personeel dit bouwen in baksteen, het bepleisteren van wanden, het leggen van cementenvloeren, het betonwerk feitelijk geheel moest worden geleerd, terwijl zoowel de materialen voor den bouw uit Suriname (balken van voor de boschnegers ongewone afmetingen) als uit Nederland dikwijls maanden op zich lieten wachten. Plaatselijk is in den regel te Paramaribo zoo goed als niets te krijgen, terwijl de levering van Surinaamsche baksteen spoedig alles te wenschen overliet in hoedanigheid en hoeveelheid. Jammer genoeg moest 't Departement van Openbare Werken voor de tweede helft der gebouwen baksteen uit Cayenne laten komen, ondanks 't feit dat klei voor klinkers hier in grooten voorraad aanwezig is en het produkt voor dat in Holland niet behoeft onder te doen. Zoo moest ook het zgn. kopergaas waarmede ramen en deuren in de plaats van glas waren voorzien nog vóór de bouw gereed was overal worden vervangen door ijzergaas, aangezien juist dit kopergaas beter (gezegd verkoperd gaas) overal op de sponningen in dit zeeklimaat was doorgeroest.

Ondanks deze kleine tegenspoeden staan nu alle 7 gebouwen der besmettelijke afdeeling overeind. Op de plaats waar nog kort geleden het oude en verouderde lijkenhuisje stond, geeft nu een sierlijke brug van gewapend beton met witte leuningen toegang tot ' $t$ ruime terrein dat een be- 
langrijke verhooging met zeeschelpen heeft ondergaan. In 't midden treedt men door een met fraaie met tegels voorziene poort de afdeeling binnen. In het hoofdgebouw bevinden zich dokters- en hoofdzusterskamer, 2 keukenkamers, 4 rijen bad- en kleedkamers, benevens de W.C.'s voor 't personeel en 2 spoelkamers. Evenals de rechterhelft van 't complexgebouw voor mannen en de linker voor vrouwen is bestemd, zoo is ook 't hoofdgebouw der besmettelijke afdeeling verdeeld in een mannel. en vrouwel. helft. Geen lijders worden opgenomen zonder de sluizen van dit hoofdgebouw, dwz. de badkamers, te zijn gepasseerd.

Van de drie paviljoens, uit welke iedere helft bestaat, is het eerste bestemd voor afzonderlijke verpleging en bevat zes kamers benevens badkamer en W.C., het tweede voor verpleging van dysenterielijders, het derde, zeer groote, voor tuberculoselijders. Beide laatsten hebben als het eerste afzonderlijke W.C., en badkamers benevens ieder een isoleerkamer voor ernstige zieken. Alle zalen zijn voorzien van galerijen, van ingebouwde waschtafels, en zijn muskieten-vrij. Muskietengordijnen zijn derhalve op deze afdeeling onnoodig. De rood cementen vloeren der zalen zijn naar het midden toe hellend gemaakt, zoodat alle spoelwater in een centrale goot kan wegvloeien. De bedden staan als in de moderne indische hospitalen met 't hoofdeinde langs de as der zaal. De patiënten zien dus allen naar buiten en niet naar elkaar, terwijl de doktersvisite buitenom wordt gebracht. Wat watervoorziening betreft is de afdeeling gedeeltelijk aangewezen op metalen waterketels op de zoldering, gedeeltelijk op hetgeen door de pompmachines van 't Militair Hospitaal over 't oude hoofdgebouw naar de nieuwe afdeeling wordt overgevoerd. Faecaliën enz. komen terecht in rottingskelders.

Ten slotte verheft zich aan 't einde van het nieuwe terrein een gebouw, oorspronkelijk niet in den bouw begrepen en dat gedeeltelijk 't afgebroken lijkenhuisje vervangt, nl. een ruim pathol. anat. laboratorium met leskamer, sectiekamer, rouwkamer, waschkamer, enz.; eene gelegenheid tot wetenschappelijk werk en studie, die tot 
440 DE NIEUWE AFDEELING VAN HET MILITAIR HOSPITAAL

nu toe in het Militair Hospitaal noode werd gemist en van welke gelegenheid de genoemde Geneeskundige School zonder twijfel veel nut zal trekken evenals ten slotte de geheele geneesk. stand in Suriname.

Onnoodig te zeggen dat aan de afwerking van het tertein nog veel te doen is. Zonder twijfel zal nog veel aan tuin-aanleg moeten worden gedaan. Dit zal met de weinige beschikbare krachten slechts in langzaam tempo kunnen geschieden. Ook dit komt echter ongetwijfeld in orde.

Moge het hier beschreven geheel blijvend bevestigen den goeden naam van de Nederl. Geneesk. Wetenschap in Zuid-Amerika en haar beoefenaars in Suriname en de kolonie zelve tot zegen zijn.

Paramaribo, 7 Juli 1924. 


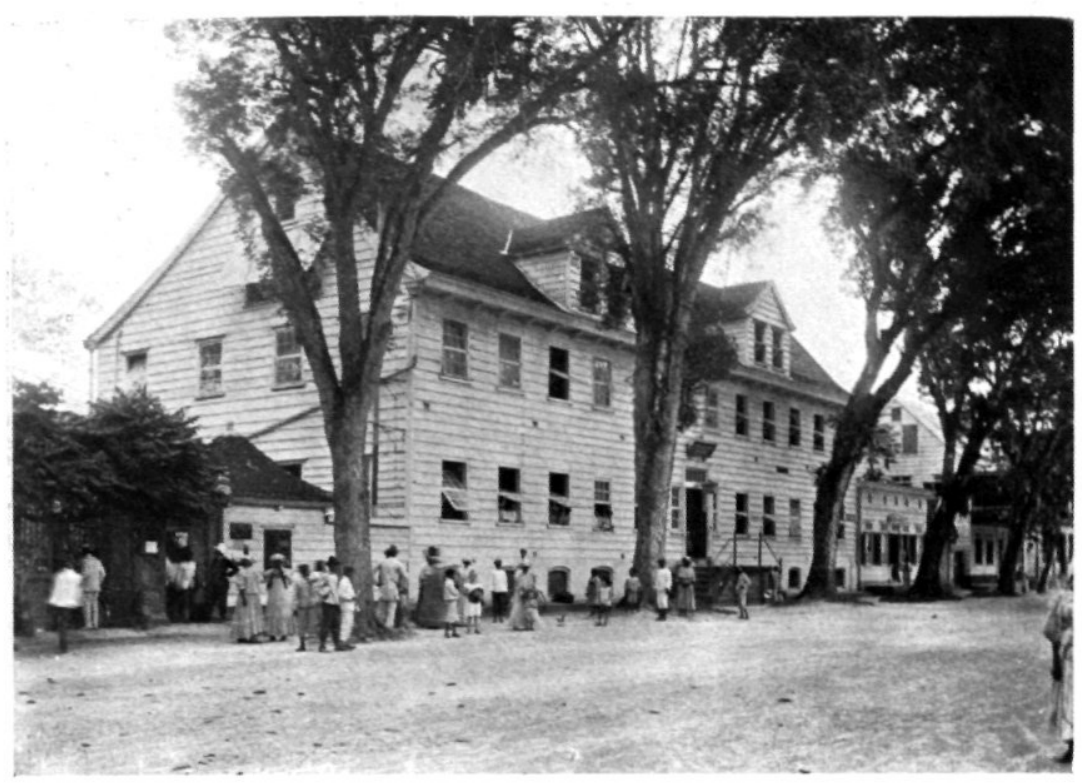

I. Eerste militaire hospitaal te Paramaribo, ${ }^{3} 75^{8}$.

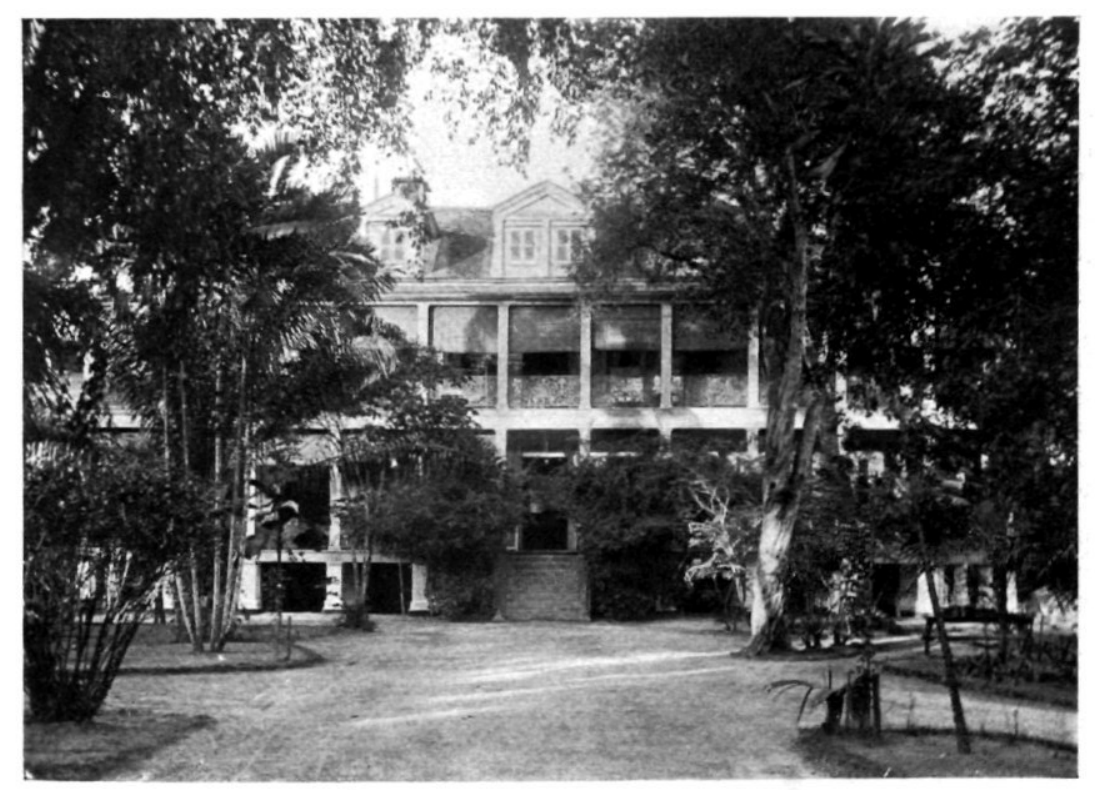

2. Hoofdgebouw (1860) militair hospitaal, front. 


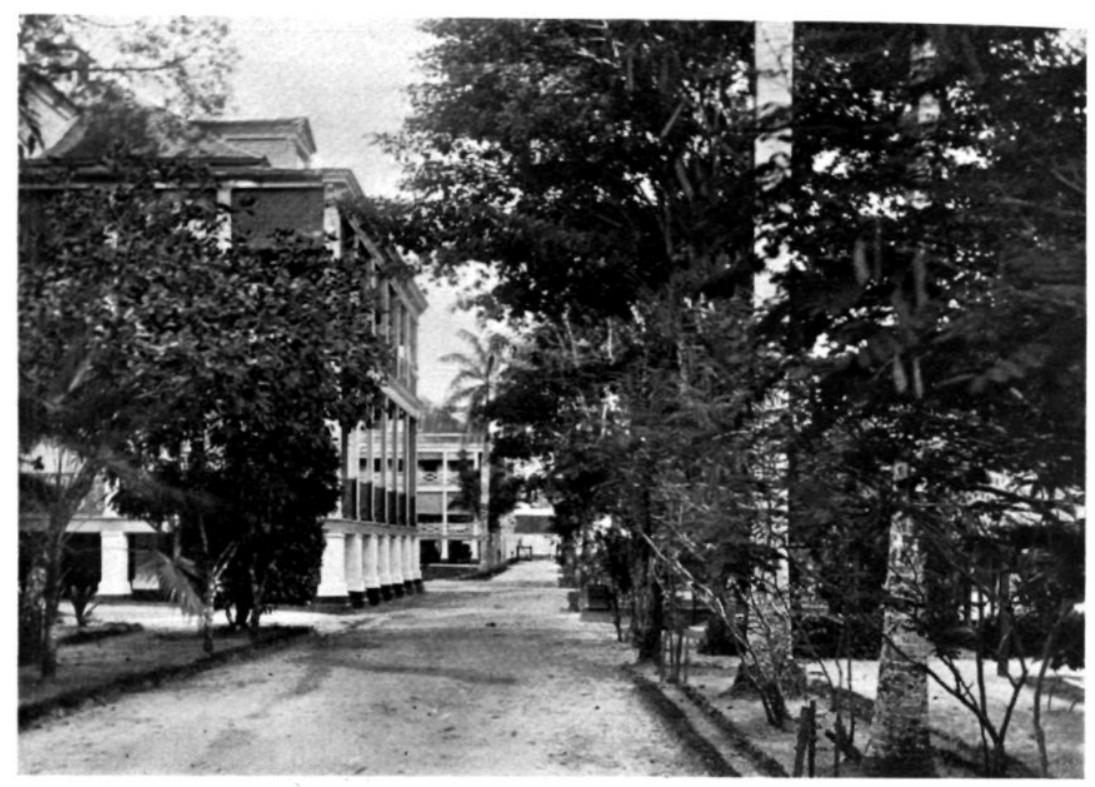

3. Rijweg langs het hoofdgebouw; het oude lijkenhuisje is nog aanwezig.

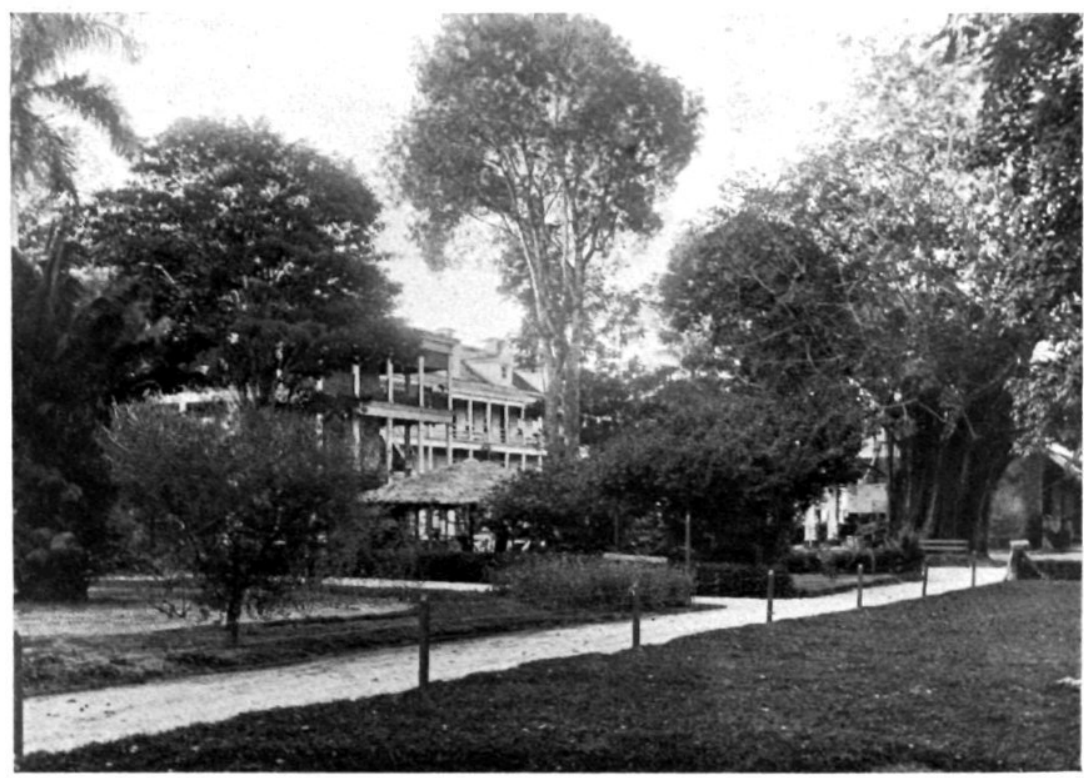

4. Hoofdgebouw militair hospitaal, van terzijde. 


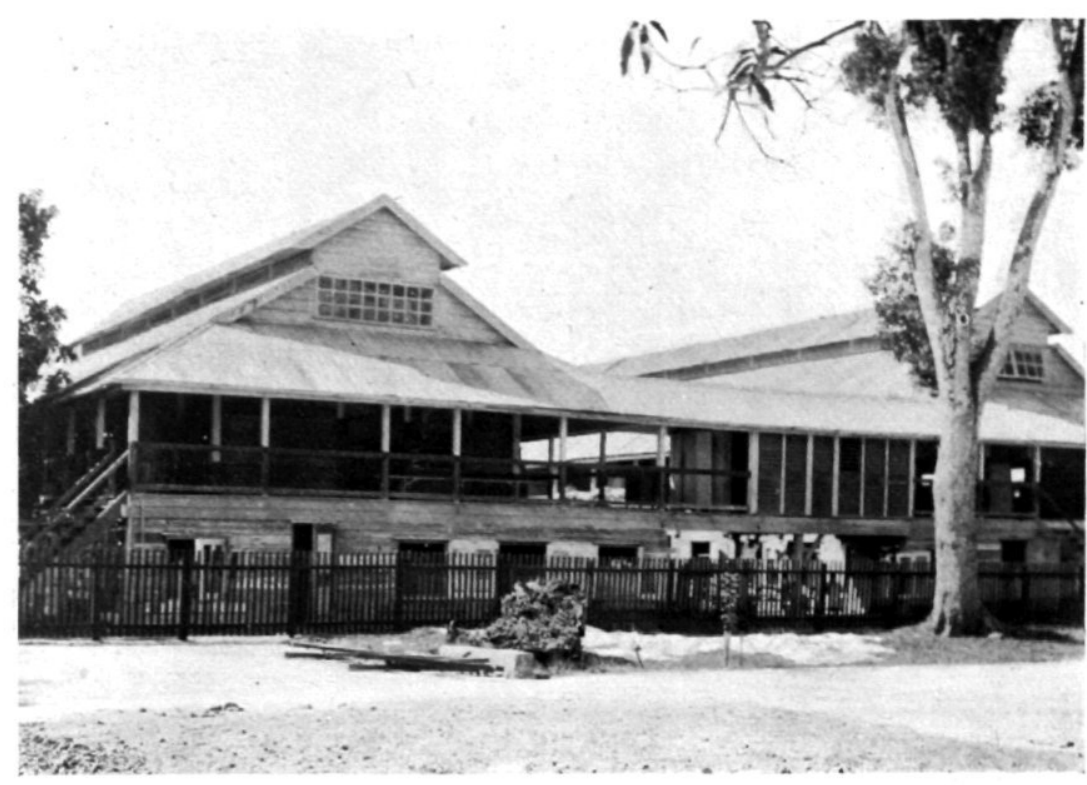

5. Oude Barak; boven typhus en dysenterie, onder de „catacomben”.

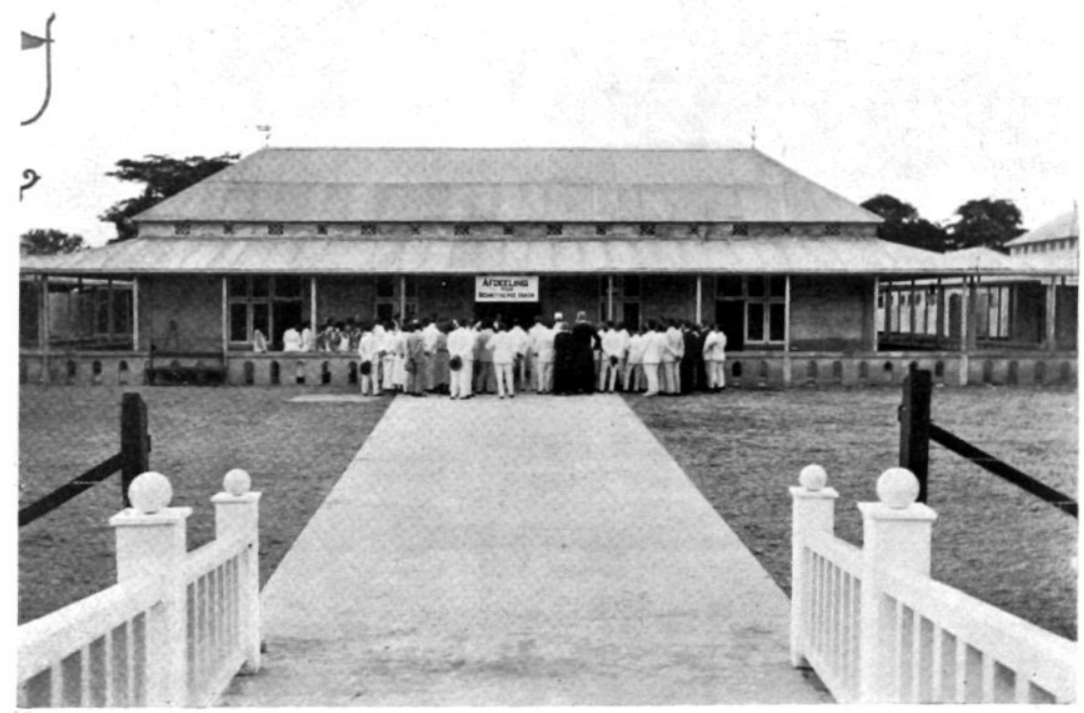

6. is Juni 1924. Opening afdeeling voor besmettelijke ziekten. (hoofdgebouw) 


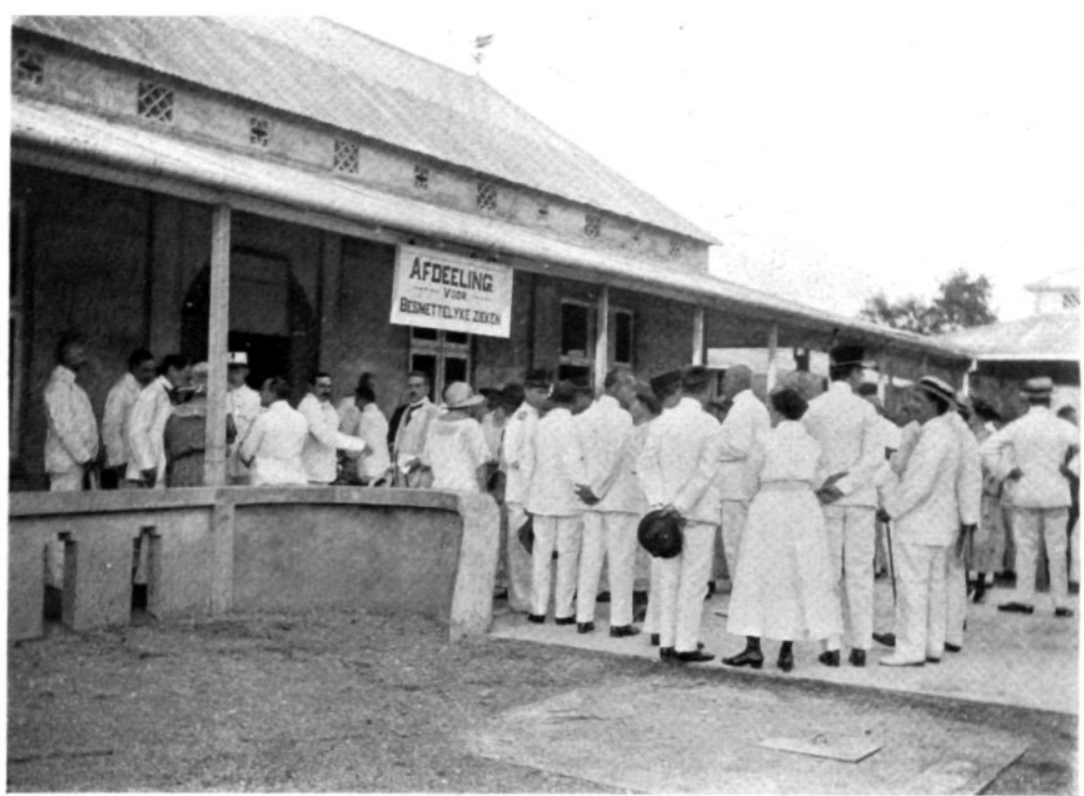
7. 1 I Juni 1924. Openingsplechtigheid nieuwe afdeeling voor
besmettelijke ziekten.

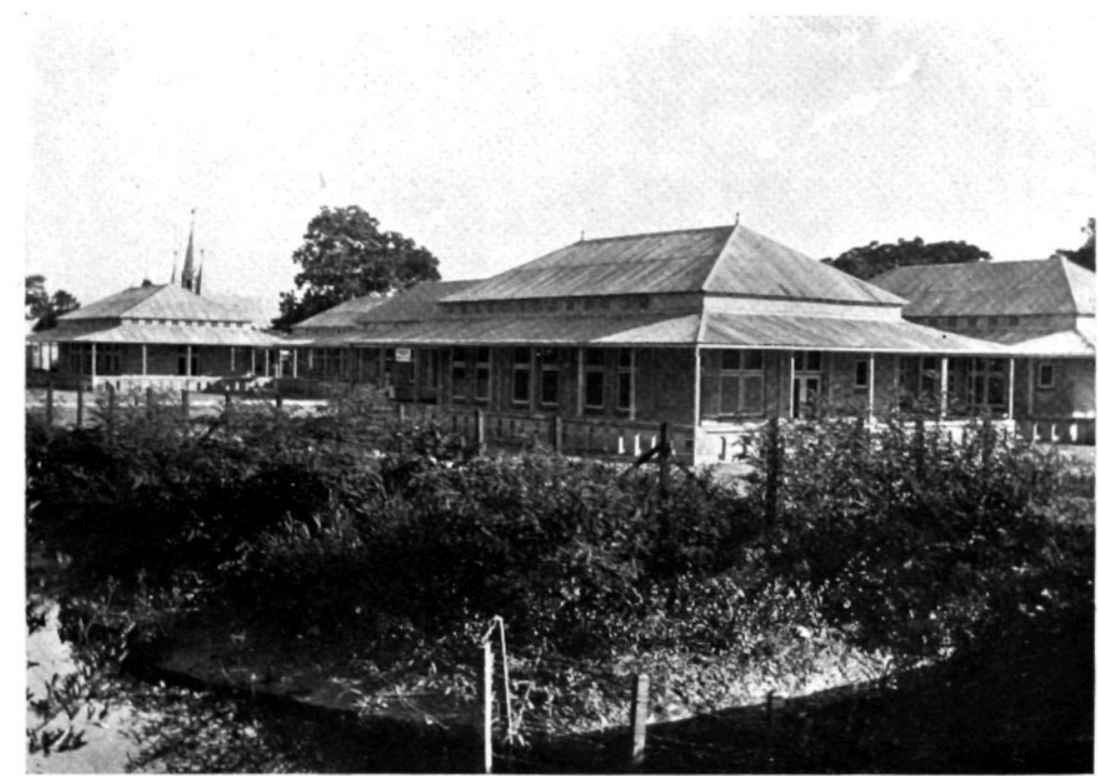

8. Nieuwe afdeeling voor besmettelijke ziekten, gezien van af brug Tourtonnelaan. 


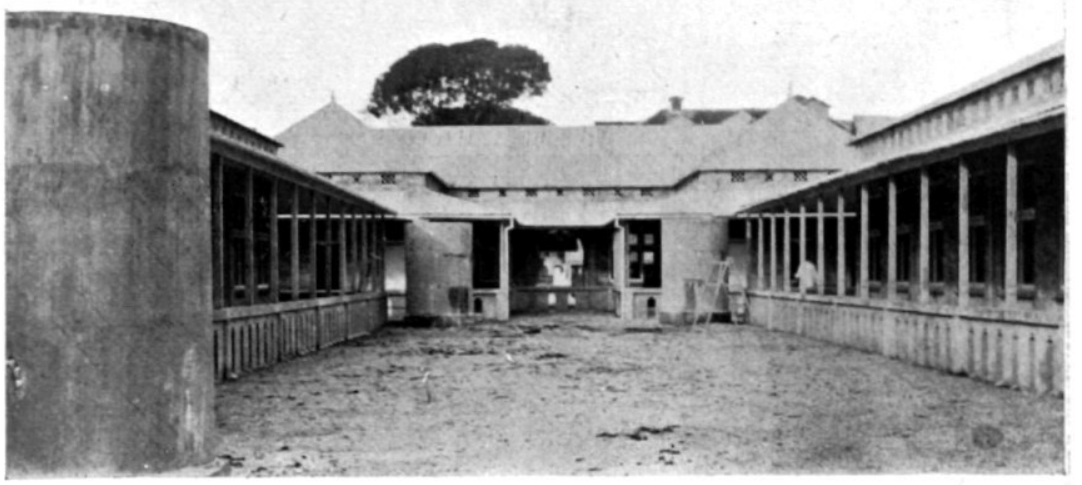

9. Juli i924. Doorzicht door het hoofdgebouw der nieuwe afdeeling voor besmettelijke ziekten naar de brug, die voert naar het terrein van het oude hospitaal. Rechts en links zalen voor tuberculoselijders. Links cementen regenbak.

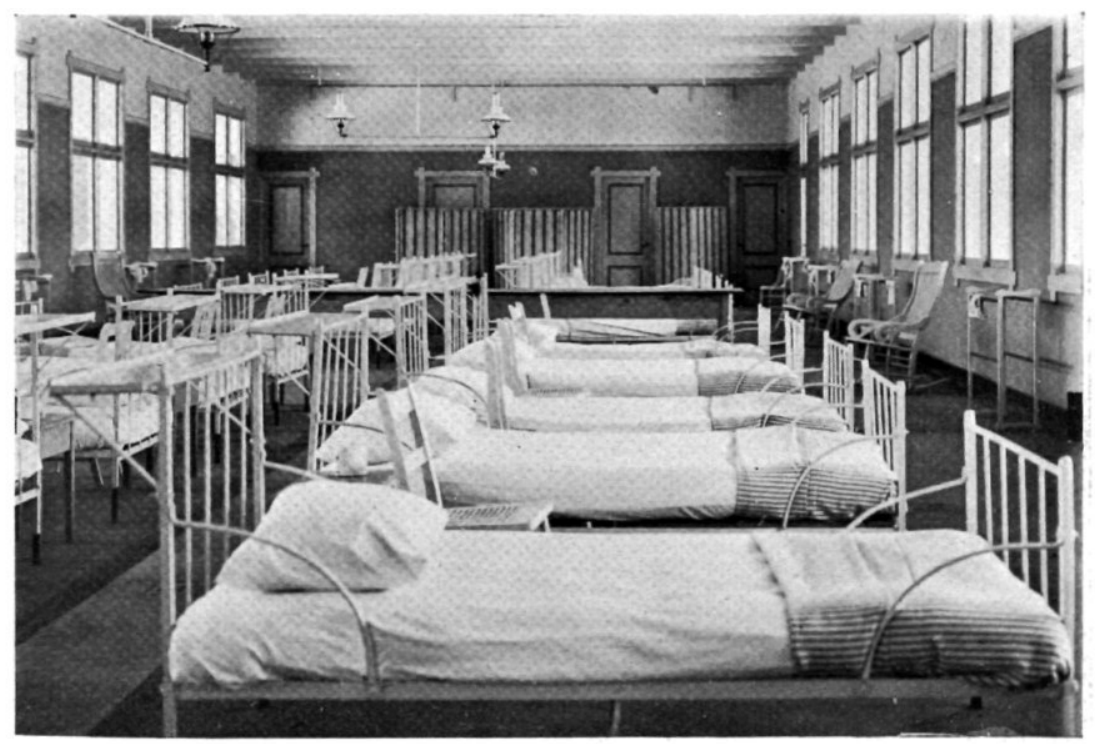

Io. Één der nieuwe paviljoens, (voor tuberculeuse vrouwen). 


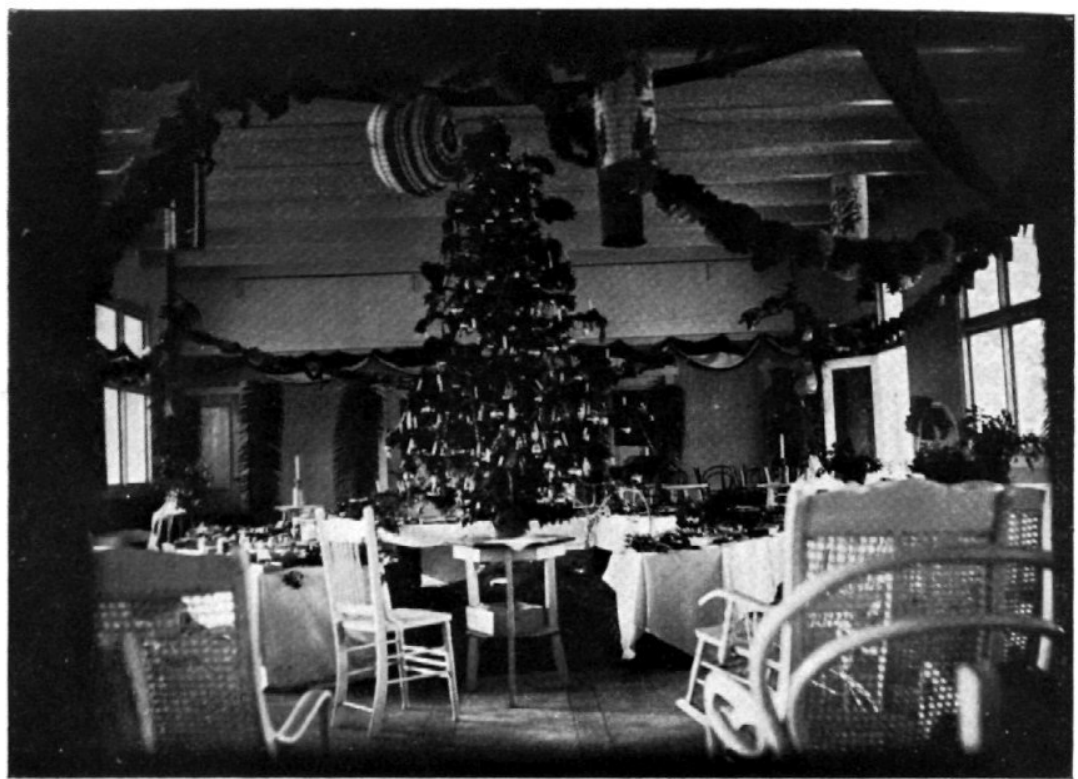

II. 28 September 1923. Kerstfeest in de nieuwe zaal.

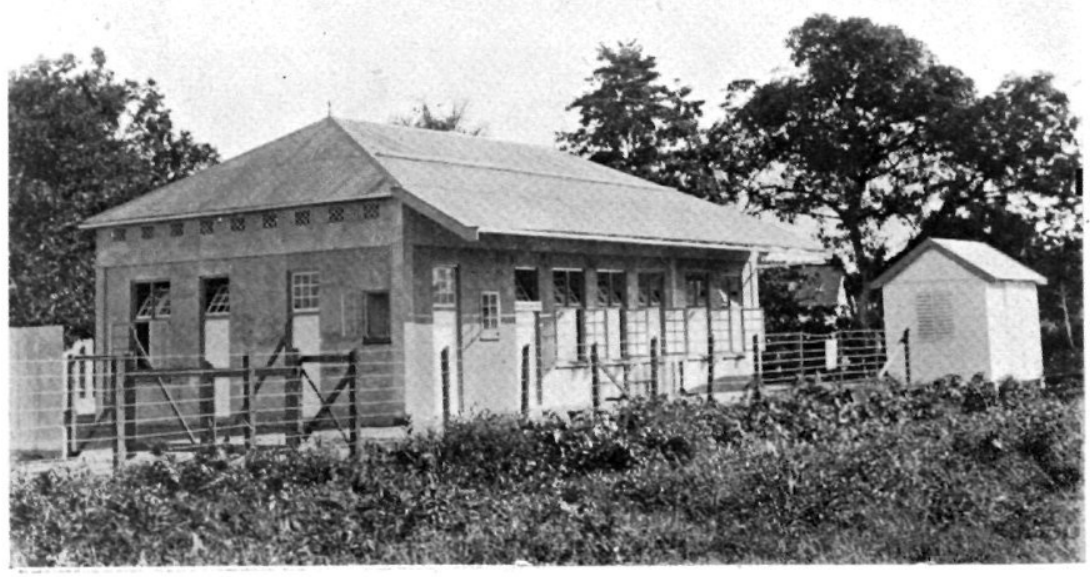

12. Juli 1924. Pathologisch-Anatomisch laboratorium. 


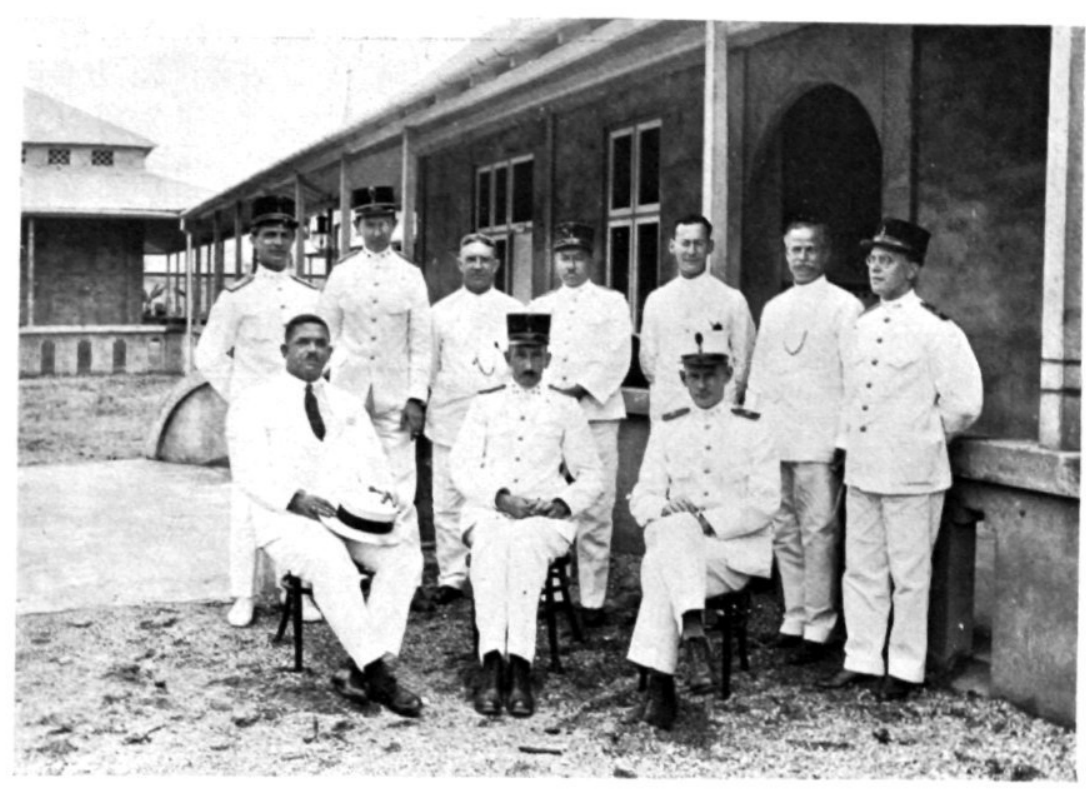

13. 9 Juni 1924. Staf militair hospitaal te Paramaribo, doktoren, apothekers, administrateurs.

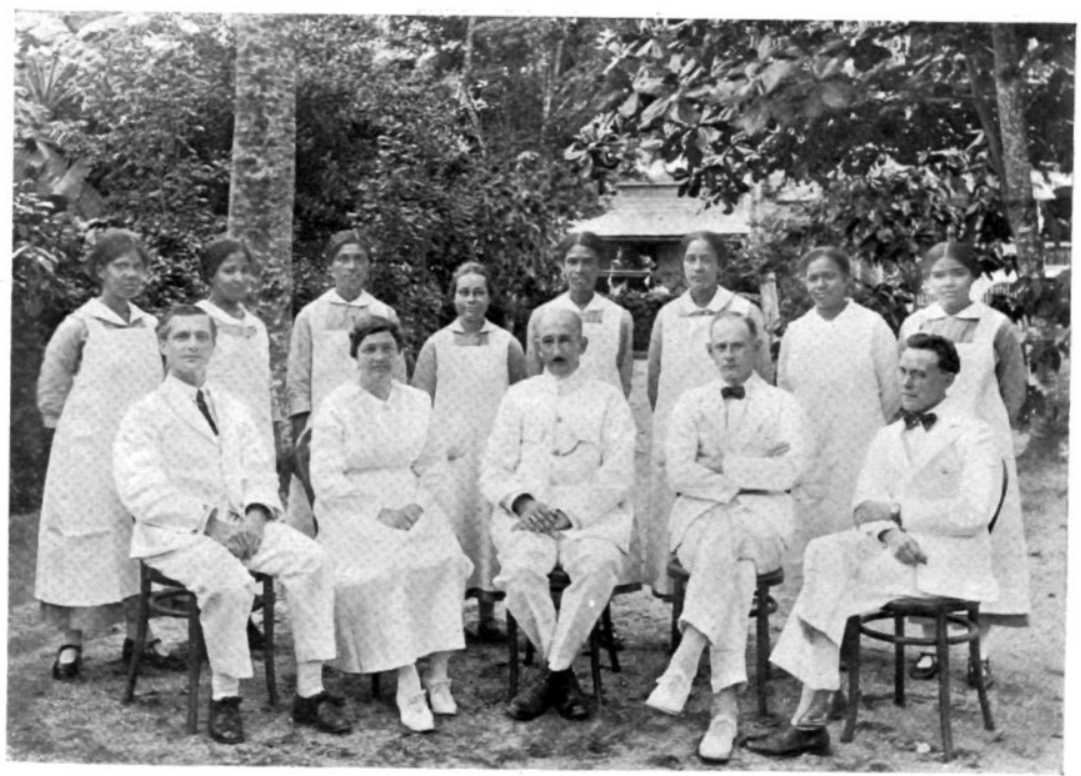

I4. Juni-I924. Cursus Ned. Bond voor ziekenverpleging; leeraren en oudste jaar. 


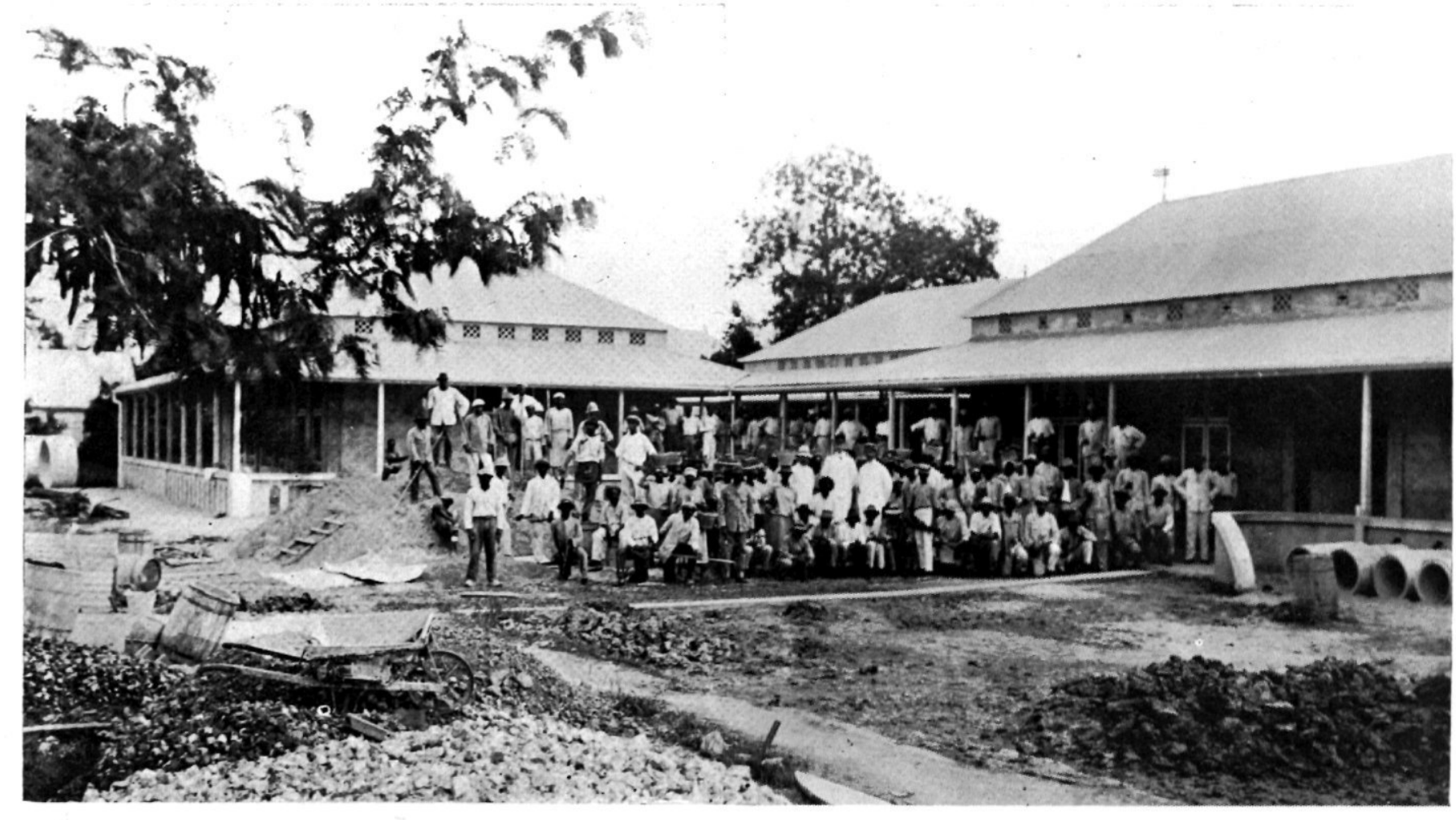

15. Mei 1923. Nieuwe afdeeling voor besmettelijke ziekten. Werkvolk, Ing. Kempees. Dr. Cool, Opzichter Neuteboom. 